\title{
PENGARUH KOMPENSASI TERHADAP KINERJA GURU PADA YAYASAN PENDIDIKAN WASKITO
}

\author{
Muhammad Gandung \\ dosen02020@unpam.ac.id \\ Dosen Universitas Pamulang
}

\begin{abstract}
ABSTRAK
Tujuan penelitian untuk mengetahui kompensasi yang diberikan Yayasan Pendidikan Waskito serta untuk mengetahui kinerja guru Yayasan Pendidikan Waskito dan seberapa besar pengaruh kompenasi terhadap kinerja guru Yayasan Pendidikan Waskito. Metode yang digunakan dalam penelitian ini adalah metode kuantitatif hal ini dimaksudkan untuk menghitung dari angket data kompensasi yang diterima guru sebagai variabel bebas (X) yang sudah diketahui dan menghitung angket data kinerja karyawan sebagai variabel tetap (Y) yang belum diketahui dari hasil angket yang disebarkan ke guru, salah satu metode yang digunakan oleh penulis adalah dengan menggunakan model-model matematika dan statistik. Dengan mentabulasi perolehan kuesioner yang kemudian menggunakan analisis korelasi product moment, Validias, Reabilitas, Determinasi dan Uji Signifikansi. Berdasarkan hasil yang diperoleh dan sudah diolah terlebih dahulu melalui perhitungan korelasi antara kompensasi terhadap kinerja karyawan diperoleh nilai $\mathrm{r}_{\mathrm{xy}}$ determinasi sebesar 0,708 dengab korelasi determinasi sebesar 50\% sedangkan 50\% dipengaruhi oleh faktor lain. Kemudian dari perhitungan uji keberartian Koefisien Korelasi (Uji-t) diperoleh nilai $\mathrm{t}_{\text {hitung }}=3,304$ dan $\mathrm{t}_{\text {tabel }}=2,000$. Ternyata $\mathrm{t}_{\text {hitung }}>\mathrm{t}$ tabel. Dengan demikian Ho ditolak, artinya terdapat hubungan yang berarti antara Kompensasi dan Kinerja Guru. Berdasarkan hasil tanggapan responden yang diperoleh dalam penelitian maka dapat diketahui bahwa kompensasi yang diberikan oleh Yayasan Pendidikan Waskito telah dilaksanakan dengan baik sehingga kinerja guru semakin membaik. Kebijakan tersebut hendaknya dipertahankan oleh perusahaan agar semangat kerja para guru tetap tinggi sehingga tujuan Yayasan Pendidikan Waskito dan keinginan para guru dapat tercapai dengan baik.
\end{abstract}

Kata kunci : Kompensasi, Kinerja

\section{PENDAHULUAN}

\section{A. Latar Belakang Masalah}

Menurut Malayu S.P. Hasibuan (2005:118), mendefinisikan Kompensasi adalah semua pendapatan yang berbentuk uang, barang langsung atau tidak langsung yang diterima karyawan sebagai imbalan atas jasa yang diberikan kepada perusahaan. 
Menurut T. Hani Handoko (2010:135), mengistilahkan kinerja (performance) dengan prestasi kerja yaitu proses melalui mana organisasi mengevaluasi atau menilai perestasi kerja karyawan.

\section{B. Identifikasi Masalah}

Penulis mengidentifikasi beberapa masalah yaitu: (1) Belum optimalnya pemberian gaji kepada guru di Yayasan Pendidikan Waskito. (2) Kurang adanya sosialisasi perhitungan kompensasi yang di terima guru oleh Yayasan Pendidikan Waskito. (3) Belum optimalnya pemberian insentif kepada guru di Yayasan Pendidikan Waskito. (4) Belum optimalnya pemberian bonus kepada guru di Yayasan Pendidikan Waskito. (5) Adanya guru yang kurang diberi motivasi.

\section{Batasan Masalah}

Untuk dapat memudahkan dalam penelitian dan mendapatkan jawaban dari rumusan masalah maka penulis memberikan beberapa batasan masalah diantaranya: (1) Yang dimaksud dengan Kompensasi adalah merupakan sesuatu yang diterima guru sebagai pengganti kontribusi jasa mereka pada Yayasan Pendidikan Waskito. (2) Yang dimaksud dengan kinerja adalah manajemen tentang menciptakan hubungan dan memastikan komunikasi yang efektif pada guru di Yayasan Pendidikan Waskito. (3) Penelitian ini dilakukan pada Yayasan Pendidikan Waskito merupakan Yayasan pendidikan yang beralamat di jalan Raya Pamulang Permai II No. 75 Serua, Kecamatan Ciputat, Tangerang Selatan yang bergerak dibidang jasa dan pelayanan, dan penelitian ini dilakukan selama 3 bulan, terhitung dari bulan April sampai dengan Juni 2013.

\section{Rumusan Masalah}

Dalam suatu penelitian penulis harus mampu untuk menemukan dan merumuskan masalah yang akan dipecahkan atau dicarikan jawaban melalui kegiatan penelitian. Untuk itu berdasarkan identifikasi masalah diatas penulis merumuskan masalah sebagai berikut: (1) Bagaimana kompensasi yang diberikan oleh Yayasan Pendidikan Waskito? (2) Bagaimana kinerja Guru pada Yayasan Pendidikan Waskito? (3) Seberapa besar pengaruh kompensasi terhadap kinerja Guru pada Yayasan Pendidikan Waskito?

\section{E. Tujuan Penelitian}

Tujuan dalam penelitian ini adalah: (1) Untuk mengetahui kompensasi yang diberikan Yayasan Pendidikan Waskito. (2) Untuk mengetahui kinerja Guru pada Yayasan Pendidikan Waskito. (3) Untuk mengetahui seberapa besar pengaruh kompensasi terhadap kinerja Guru pada Yayasan Pendidikan Waskito

Melalui penelitian ini diharapkan dapat memberikan manfaat yaitu: (a) Untuk Penulis : (1) Menambah wawasan dan menjadi jembatan ilmu yang akan berguna bagi penulis, dan memenuhi syarat untuk mencapai gelar sarjana ekonomi strata 1. (b) Pihak organisasi/lembaga : (a) diharapkan dengan adanya penelitian ini dapat 
memperoleh masukan-masukan yang positif dan membangun, yang dapat diterapkan organisasi/lembaga dalam usaha meningkatkan kinerja guru. (c) Untuk Akademik : (1) Bagi pihak-pihak lain yang turut membaca diharapkan agar dapat menambah wawasan dan pengetahuan sesuai dengan topik penulisan dan sebagai sumbangan pemikiran tentang pengetahuan di bidang sumber daya manusia khususnya tentang kompensasi dan kinerja.

\section{F. Hipotesis Penelitian}

Hipotesis adalah merupakan jawaban sementara terhadap rumusan masalah penelitian, di mana rumusan masalah penelitian telah dinyatakan dalam bentuk kalimat pertanyaan. Dikatakan sementara, karena jawaban yang di berika baru didasarkan pada teori yang relevan, belum didasarkan pada fakta-fakta empiris yang di peroleh melalui pengumpulan data. Jadi hipotesis juga dapat dinyatakan sebagai jawaban teoritis terhadap rumusan masalah penelitian, belum jawaban yang empirik.

\section{TINJAUAN PUSTAKA}

\section{A. Manajemen}

Menurut Malayu Hasibuan (2005:1) Manajemen berasal dari kata to manage yang artinya mengatur. Timbul pertanyaan tentang: apa yang diatur, apa tujuannya diatur, mengapa harus diatur, siapa yang mengatur, dan bagaimana mengaturnya sebagai berikut:

1. Yang diatur adalah semua unsur manajemen yakni $6 \mathrm{M}$ (man, money, method, machines, materials, and market).

2. Tujuannya diatur adalah agar $6 \mathrm{M}$ lebih berdaya guna dan berhasil guna dalam mewujudkan tujuan.

3. Harus diatur supaya $6 \mathrm{M}$ itu bermanfaat optimal, terkoordinasi, dan terintegrasi dengan baik dalam menunjang terwujudnya tujuan organisasi.

4. Yang mengatur adalah pimpinan dengan kepemimpinan yaitu pimpinan puncak, manajer madya, dan supervise.

5. Mengaturnya adalah dengan melakukan kegiatan urut-urutan fungsi manajemen tersebut.

Berikut ini akan penulis kemukakan beberapa pengertian manajemen, yaitu :

Menurut Malayu Hasibuan (2005:1) Manajemen adalah ilmu dan seni mengatur proses pemanfaatan sumber daya manusia dan sumber-sumber lainnya secara efektif dan efisien untuk mencapai suatu tujuan tertentu.

\section{B. Manajemen Sumber Daya Manusia}

Menurut Ike Kusdyah Rachmawati (2008:3) Manajemen Sumber Daya

Manusia adalah merupakan suatu proses perencanaan, pengorganisasian, pengarahan dan pengawasan kegiatan-kegiatan pengadaan, pengembangan, pemberian kompensasi, pengintegrasian, pemeliharaan dan pelepasan sumber daya manusia agar tercapai berbagai tujuan individu, organisasi dan masyarakat. 
Menurut Triton PB dalam (Amstrong, 2003:4) menyebutkan bahwa terminology MSDM, terlepas apakah suka ataupun tidak suka, telah dicatat dalam kosa kata manajemen sebagai pengganti untuk "manajemen personalia".

\section{Komponen Manajemen Sumber Daya Manusia}

Komponen manajemen sumber daya manusia yang utama menurut Malayu Hasibuan (2005:12) terdiri dari tiga hal yaitu:

1. Pengusaha

Pengusaha adalah setiap orang yang menginvestasikan modalnya untuk memperoleh pendapatan dan besarnya pendapatan itu tidak menentu tergantung pada laba yang dicapai perusahaan tersebut.

2. Karyawan

Karyawan merupakan aset perusahaan yang sangat berharga yang harus dijaga oleh perusahaan. Meskipun karyawan hanya sebagai penjual jasa yang telah dibeli oleh perusahaan dengan kesepakatan perjanjian antara kedua belah pihak. Karyawan dalam perusahaan dibedakan menjadi beberapa golongan yaitu:

a. Karyawan Operasional

Karyawan operasional adalah setiap orang yang secara langsung mengerjakan sendiri pekerjaannya sesuia dengan perintah atasan.

b. Karyawan Manajerial

Karyawan manajerial adalah setiap orang yang berhak memerintah bawahannya untuk mengerjakan sebagian pekerjaannya dan dikerjakan sesuai dengan perintah. Mereka mencapai tujuannya melalui kegiatan-kegiatan orang lain.

3. Pemimpin atau Manajer

Pemimpin adalah seseorang yang mempergunakan wewenang dan kepemimpinannya untuk mengarahkan orang lain serta bertanggung jawab atas pekerjaan orang tersebut dalam mencapai suatu tujuan. Setiap pemimpin atau manajer adalah termaksud manajer personalia, karena tugasnya mengatur personel yang menjadi bawahannya.

\section{Paradigma Manajemen Sumber Daya Manusia}

Paradigma (Model) manajemen sumber daya manusia yang dikemukakan oleh Henry Simamora (2004: 8) adalah sebagai berikut :

a. Model Klerikal (Clerical model)

Dalam model ini, fungsi departemen sumber daya manusia yang utama adalah membuat dan menyimpan laporan, data, catatan dan melaksanakan tugas rutin. Peran departemen sumber daya manusia didalam model ini cenderung pasif dan lemah. Apabila ada masalah manajemen sumber daya manusia yang kompleks dan mendesak maka masalah itu akan bahkan mereka, atau bahkan diabaikan.

b. Model Hukuman (Legal model)

Dalam model ini kiprah manajemen sumber daya manusia memperoleh kekuatannya dari keahlian dibidang hukum. Implikasi model hukum terhadap departemen sumber daya manusia adalah bahwa model ini memposisikan 
departemen sumber daya manusia sebagai penilai aktif terhadap sterategi, terutama yang terkait dengan implikasi hukum atas sterategi tersebut.

c. Model Financial (Finance model)

Dalam model financial ini, aspek financial manajemen sumber daya manusia sering dapat sorotan karena para manajer semakin menyadari kuatnya dampak biaya sumber daya manusia terhadap perusahaan.

d. Model manajerial (Managerial model)

Memiliki dua versi model, yaitu :

1) Versi pertama manajemen sumber daya manusia memahami kerangka acuan kerja manajer lini yang berorientasi pada produktivitas. Mereka berbagai tujuan, nilai dan pandangan pada manajer lini, dan mengambil keputusan yang bersesuaian.

2) Versi kedua manajer lini melaksanakan beberapa fungsi sumber daya manusia diantara melatih manajer dalam keahlian yang diperlukan untuk menangani fungsi kunci sumber daya manusia seperti rekrutmen, evaluasi kinerja dan pengembangan.

3) Model Humanistik (humanistic model)

Ide sentral dalam model humanistik adalah bahwa departemen sumber daya manusia dibentuk untuk mengembangkan nilai dan potensi sumber daya manusia dalam organisasi.

4) Model Ilmu perilaku

Moedel ini perilaku menganggap bahwa ilmu perilaku seperti psikologi dan perilaku organisasi merupakan basis aktivitas sumber daya manusia. Prinsipnya adalah bahwa sebuah pendekatan sains terhadap perilaku manusia dapat diterapkan pada hampir semua persoalan.

\section{E. Pengertian Kompensasi}

Menurut Veithzal Rivai (2010:741), kompensasi adalah merupakan sesuatu yang diterima karyawan sebagai pengganti kontribusi jasa mereka pada perusahaan.

Menurut Akhmad Subekhi \& Mohammad Jauhar dalam (Malayu Hasibuan 2003:117) mendefinisikan: Kompensasi merupakan pengeluaran dan biaya bagi perusahaan. Perusahaan mengharapkan agar kompensasi yang dibayarkan memperoleh imbalan prestasi kerja yang lebih besar dari karyawanak langsung yang diterima karyawan. Jadi, nilai prestasi kerja karyawan harus lebih besar dari kompensasi yang dibayar perusahaan, supaya perusahaan mendapatkan laba dan kontuinitas perusahaan terjamin. Kompensasi adalah pendapatan yang berbentuk uang, barang langsung atau tidak langsung yang diterima karyawan sebagai imbalan atas jasa yang diberikan kepada perusahaan.

Menurut Ike Racmawati (2007:144), Kompensasi adalah segala sesuatu yang diterima oleh karyawan sebagai balas jasa untuk kerja mereka. 


\section{F. Tujuan Pemberian Kompensasi}

Tujuan pemberian kompensasi menurut Malayu Hasibuan (2005:121) antara lain:

a. Ikatan kerja sama

pemberian kompensasi terjalinlah ikatan kerja sama formal antara majikan dengan karyawan. Karyawan harus mengerjakan tugas-tugasnya dengan baik, sedangkan pengusah/majikan wajib membayar kompensasi sesuai dengan perjanjian yang disepakati.

b. Kepuasan kerja

Dengan balas jasa, karyawan akan dapat memenuhi kebutuhan-kebutuhan fisik, status sosial, dan egoitiknya sehingga memperoleh kepuasan kerja dari jabatannya.

c. Pengadaan efektif Jika program kompensasi ditetapkan cukup besar, pengadaan karyawan yang qualified untuk perusahaan akan lebih mudah.

d. Motivasi

Jika balas jasa yang diberikan cukup besar, manajer akan mudah memotivasi bawahannya.

e. Stabilitas pegawai

Dengan program kompensasi atas prinsip adil dan layak secara eksternal konsistensi yang kompentatif maka stabilitas karyawan akan lebih terjamin karena turn over relative kecil.

f. Disiplin

Dengan pemberian balas jasa yang cukup besar maka disiplin karyawan semakin baik. Mereka akan menyadari serta mentaati peraturan-peraturan yang berlaku.

g. Pengaruh serikat buruh

Dengan program kompensasi yang baik pengaruh serikat buruh dapat dihindarkan dan karyawan akan berkonsentrasi pada pekerjaannya.

h. Pengaruh pemerintah

Jika program kompensasi sesuai dengn undang-undang perburuhan yang berlaku (seperti batas upah minimum) maka intervensi pemerintahan dapat dihindarkan.

\section{G. Pengertian Kinerja}

Menurut M. B. Tika dalam (Akhmad Subekhi \& Mohammad Jauhar, 2012:194), Pengertian Kinerja adalah telah dirumuskan oleh beberapa ahli manajemen sebagai berikut:

a. Stnoner (1978) mengemukakan bahwa kinerja adalah fungsi dari motivasi, kecakapan, dan persepsi peranan.

b. Bernadin dan Russel (1993) (dalam Achmad S. Ruky) mendefinisikan kinerja sebagai pencatatan hasil-hasil yang diperoleh dari fungsi-fungsi pekerjaan atau kegiatan tertentu selama kurun waktu tertentu.

c. Handoko mendefinisikan kinerja sebagai proses dimana organisasi mengevaluasi atau menilai prestasi kerja karyawan. 
d. Prawiro Suntoro (1999) (dalam Merry Dandian Panji) kinerja adalah hasil kerja yang dapat dicapai seseorang atau sekelompok orang dalam suatu oraganisasi dalam rangka mencapai tujuan organisasi dalam periode waktu tertentu.

\section{H. Faktor-faktor yang mempengaruhi kinerja}

Menurut Prabu Mangkunegara (dalam Khaerul Umam 2010:189) menyatakan bahwa faktor yang mempengaruhi kinerja antara lain:

a. Faktor kemampuan

Secara psikologis, kemampuan (ability) pegawai terdiri dari kemampuan potensi $(I Q)$ dan kemampuan reality (knowledge + skill). Artinya, pegawai yang memiliki $I Q$ diatas rata-rata (IQ 110-120) dengan pendidikan yang memadai untuk jabatannya dan terampil dalam mengerjakan pekerjaan sehari-hari, maka ia akan lebih mudah mencapai kinerja yang diharapkan. Oleh karena itu, pegawai perlu ditempatkan pada pekerjaan yang sesuai dengan keahliannya (the righ man in the righ place, the righ man on the righ job)

b. Faktor Motivasi

Motivasi terbentuk dari sikap (attitude) seorang pegawai dalam menghadapi situasi (situation) kerja. Motivasi merupakan kondisi yang menggerakan diri pegawai yang terarah untuk mencapai tujuan organisasi (tujuan kerja).

Sedangkan faktor yang mempengaruhi kinerja menurut Amstrong dan Baron (1998:16) dalam (Wibowo 2012:100) yaitu:

a. Personal factor, ditunjukan oleh tingkat keterampilan, kompetensi, yang dimiliki, motivasi, komitmen, individu.

b. Leadership factor, ditentukan oleh kualitas dorongan, bimbingan, dan dukungan yang dilakukan manajer dan team leader.

c. Team factor, ditunjukan oleh kualitas dukungan yang diberikan oleh rekan sekerja.

d. Sytem factor, ditunjukan oleh adanya system kerja dan fasilitas yang diberikan organisasi.

Contextual/situational factor, ditunjukan oleh tingginya tingkat tekanan dan perubahan lingkungan internal dan eksternal.

\section{METODOLOGI PENELITIAN}

\section{A. Tempat Penelitian dan Waktu Penelitian}

Dalam penelitian ini peneliti mengambil lokasi penelitian pada Yayasan Pendidikan Waskito, yang beralamat di jalan Raya Pamulang Permai II No. 75 Serua, Kecamatan. Ciputat, Tangerang Selatan. Dan penelitian dilaksanakan 3 bulan.

\section{B. Jenis Penelitian}

Sifat penelitian yang dipergunakan dalam penelitian ini adalah dengan analisis kuantitatif yaitu dengan mendeskripsikan keadaan responden serta deskripsi variabel penelitian dalam table frekuensi dan prosentase dari hasil penyebaran angket dengan melalui prosedur analisis data yaitu penelitian lapangan, wawancara dan kuesioner. 


\section{Populasi dan Sample}

Berdasarkan pada tempat penelitian yang telah ditetapkan, maka populasi yang dijadikan objek dalam penelitian ini adalah seluruh guru pada Yayasan Pendidikan Waskito yang berjumlah 60 guru. Dan Mengingat besarnya populasi kurang dari 100, maka tidak dilakukan sampling atau pengambilan sampel hal ini mengacu pada pendapat Suharsimi (2006:120) yang menyatakan bahwa apabila subjeknya kurang dari 100, lebih baik diambil semuaya sehingga penelitiannya merupakan penelitian populasi. Sehingga peneliti mengambil seluruh populasi yang berjumlah 60 untuk diteliti.

\section{Teknik Pengumpulan Data}

Metode pengumpulan data dengan membuat daftar pernyataan (kuesioner) yang diberikan kepada guru atau responden dan dikumpulkan kembali. Adapun metode pengumpulan data yang dilakukan penulis dalam penelitian ini dengan menggunakan cara studi lapangan yang dapat dilakukan menurut Sugiyono (2011:137) yaitu wawancara, kuisioner dan observasi.

\section{E. Metode Analisis Data}

Untuk mengumpulkan data tentang varibel bebas $(\mathrm{X})$ dan variabel terikat (Y) digunakan angket (kuesioner). Terdiri dari pernyataan dimana jawabannya yaitu sangat setuju, ragu, tidak setuju, sangat tidak setuju yang mengacu pada skala likert

\section{PEMBAHASAN DAN HASIL PENELITIAN}

\section{A. Gambaran Umum Objek Penelitian}

Pada tahun 1966 Yayasan Pendidikan Waskito didirikan oleh Alm Ray Siti Susantinah dijalan setia budi raya no. 1 jakarta selatan, dan berawal dari penitipan anak. Setelah 6 bulan berjalan, kemudian memiliki SD kelas 6 dari sekolah yang sudah tidak berjalan KBM (kegiatan belajar mengajar), 1 tahun kemudian dilanjutkan SD kelas 1, SMP kelas 1 pada tahun 1968, perkembangan sampai tahun 1969 dibuka Waskito 2 di Karet pedurenan, tahun 1975 dibuka sekolah di Jawa Barat di desa Kedaung Kecamatan Ciputat, tahun 1990 di SD karet pedurenan dan SD, di Seti Budi tergusur dengan adanya perkembangan kota, kemudian SMP, SMA pindah ke Pondok Labu, dan berakhir KBM tahun 1993, karena memfokuskan pendidikan di wilayah Tangerang.

Tahun 1990 di bangun sekolah TK, SD, SMP di jalan Pamulang Permai 2 no. 75 Sarua Ciputat, setelah berkembang kemudian didirikan SMEA Waskito dengan jurusan Administrasi perkantoran dan sampai saat ini mendapat akreditasi B dan memiliki 286 siswa-siswi. 


\section{B. Uji Validitas dan Reliabilitas Instrumen \\ Validitas Instrumen Kompensasi (X) \\ r hitung}

\begin{tabular}{|c|c|c|c|c|}
\hline $\begin{array}{c}\text { No } \\
\text { Pertanyaan }\end{array}$ & $\begin{array}{c}\text { Koefisien } \\
\text { Korelasi } \\
(\mathrm{r} \text { hitung) }\end{array}$ & $\begin{array}{c}\text { Koefisien } \\
\text { Korelasi } \\
(\mathrm{t} \text { hitung) }\end{array}$ & $\begin{array}{l}\text { Distribusi } \\
(\mathrm{t} \text { tabel })\end{array}$ & Keterangan \\
\hline 1 & 0,398999 & 3,304 & 2,000 & Valid \\
\hline 2 & 0,543327 & 4,944 & 2,000 & Valid \\
\hline 3 & 0,695078 & 7,360 & 2,000 & Valid \\
\hline 4 & 0,655662 & 6,211 & 2,000 & Valid \\
\hline 5 & 0,426642 & 3,588 & 2,000 & Valid \\
\hline 6 & 0,543363 & 4,922 & 2,000 & Valid \\
\hline 7 & 0,655915 & 6,211 & 2,000 & Valid \\
\hline 8 & 0,753144 & 8,714 & 2,000 & Valid \\
\hline 9 & 0,702196 & 7,722 & 2,000 & Valid \\
\hline 10 & 0,712284 & 7,508 & 2,000 & Valid \\
\hline
\end{tabular}

Dari tabel di atas menunjukan bahwa nilai keseluruhan uji validitas (thitung) memiliki nilai yang lebih besar dari pada nilai $t$ tabel yaitu 2,000 atau thitung $>t$ tabel . Butir nilai validitas terendah terdapat pada butir kesatu yaitu sebesar 3,304 dan yang tertinggi terdapat pada butir kedelapan yaitu sebesar 8,714.Dapat disimpulkan bahwa ke-10 butir pernyataan tersebut dinyatakan Valid.

\begin{tabular}{|c|c|c|c|c|}
\hline \multicolumn{5}{|c|}{ Validitas Instrumen Kinerja (Y) } \\
\hline \multirow{3}{*}{$\begin{array}{c}\text { No } \\
\text { Pertanyaan }\end{array}$} & \multirow{3}{*}{$\begin{array}{c}\text { Koefisien } \\
\text { Korelasi } \\
\text { (r hitung) }\end{array}$} & \multirow{3}{*}{\begin{tabular}{|c|} 
Koefisien \\
Korelasi \\
(t hitung)
\end{tabular}} & \multirow{3}{*}{$\begin{array}{c}\text { Distribusi } \\
(\mathrm{t} \text { tabel })\end{array}$} & \multirow{3}{*}{ Keterangan } \\
\hline & & & & \\
\hline & & & & \\
\hline 1 & 0,48215 & 4,189 & 2,000 & Valid \\
\hline 2 & 0,669208 & 7,625 & 2,000 & Valid \\
\hline 3 & 0,589398 & 5,684 & 2,000 & Valid \\
\hline 4 & 0,395842 & 3,275 & 2,000 & Valid \\
\hline 5 & 0,589859 & 5,550 & 2,000 & Valid \\
\hline 6 & 0,679962 & 7,043 & 2,000 & Valid \\
\hline 7 & 0,68377 & 6,296 & 2,000 & Valid \\
\hline 8 & 0,755462 & 8,777 & 2,000 & Valid \\
\hline 9 & 0,705527 & 7,571 & 2,000 & Valid \\
\hline 10 & 0,587719 & 5,154 & 2,000 & Valid \\
\hline
\end{tabular}

Dari tabel di atas menunjukan bahwa nilai keseluruhan uji validitas (thitung) memiliki nilai yang lebih besar dari pada nilai $t$ tabel yaitu 2,000 atau thitung $>t$ tabel . Butir nilai validitas terendah terdapat pada butir keempat yaitu sebesar 3,275 dan 
yang tertinggi terdapat pada butir kedelapan yaitu sebesar 8,777. Dapat disimpulkan bahwa ke-10 butir pernyataan tersebut dinyatakan Valid.

Menghitung koefisien cronchbach alpha Variabel Kompensasi (X) :

$\mathrm{rca}=\left[\frac{\mathrm{k}}{(\mathrm{k}-1)}\right]\left[1-\frac{\sum \mathrm{si}^{2}}{\mathrm{st}^{2}}\right]=\left[\frac{10}{(10-1)}\right]\left[1-\frac{9,882222}{36,74889}\right]=[1,111111][1-0,268912]=$ $[1,111111][0,731088]=0,81232$

keterangan maka $r$ tabel atau 0,81232>0,254 dengan ketentuan maka besar.

$\mathrm{r}$ tabel $>0,254$

Menghitung koefisien cronchbach alpha Variabel Kinerja (Y) :

$\mathrm{rca}=\left[\frac{\mathrm{k}}{(\mathrm{k}-1)}\right]\left[1-\frac{\sum \mathrm{si}^{2}}{\mathrm{st}^{2}}\right]=\left[\frac{10}{(10-1)}\right]\left[1-\frac{7,839722}{30,59417}\right]=[1,111111][1-0,256249]=$ $[1,111111][0,743751]=0,82639$

keterangan maka $r$ tabel atau 0,82639>0,254 dengan ketentuan maka besar. $\mathrm{r}$ tabel $>$ 0,254

\section{Analisis Korelasi Pengaruh Kompensasi (X) terhadap Kinerja (Y)}

Keterangan:

$r_{x y}=$ Koefisien korelasi

$\mathrm{X}=$ Jumlah jawaban (Kompensasi)

$\mathrm{Y}=$ Jumlah jawaban (Kinerja)

$\mathrm{X}^{2}=$ Jumlah kuadrat item pernyataan $\mathrm{X}$

$\mathrm{Y}^{2}=$ Jumlah kuadrat item pernyataan $\mathrm{Y}$

$\mathrm{n}=$ Jumlah sampel

$r_{x y}=\frac{\mathrm{n} \sum x y-\left(\sum x\right)\left(\sum \mathrm{y}\right)}{\sqrt{\left\{\mathrm{n} \sum x^{2}-\left(\sum x\right)^{2}\right\}\left\{\mathrm{n} \sum \mathrm{y}^{2}-\left(\sum y\right)^{2}\right\}}}$

$r_{x y}=\frac{(60.89872)-(2192)(2421)}{\sqrt{\left\{(60.82286)-(2192)^{2}\right\}\left\{(60.99523)(2421)^{2}\right\}}}$

$r_{x y}=\frac{(5392320)-(5306832)}{\sqrt{\{4937160-4804864\}\{5971380-5861241\}}}$

$r_{x y}=\frac{85488}{\sqrt{\{132296\}\{110139\}}}$

$r_{x y}=\frac{85488}{\sqrt{14570949144}}$

$r_{x y}=\frac{85488}{120710,18}$

$r_{x y}=0,7082087$

$r_{x y}=0,708$ 
Berdasarkan perhitungan di atas angka koefisien korelasi adalah sebesar 0,7082087 berarti hubungan pengaruh Kompensasi terhadap Kinerja Guru Kuat kaitannya. Hal ini mengacu pada tabel 4.4 bahwa $(0,60-0,799)$ dinyatakan Kuat.

\section{Koefisien Determinasi}

Kemudian untuk mengetahui besar kontribusi variabel $\mathrm{X}$ terhadap variabel $\mathrm{Y}$, digunakan koefisien determinasi $(\mathrm{R})$ dengan rumus sebagai berikut:

$\mathrm{KD}=r^{2} \mathrm{x} 100 \%$

Keterangan :

$\mathrm{KD}=$ koefisien determinasi

$r^{2}=$ koefisien korelasi $\mathrm{X}$ dan $\mathrm{Y}$

$\mathrm{KD}=(0,708)^{2} \times 100 \%$

$\mathrm{KD}=0,501 \times 100 \%$

$\mathrm{KD}=50,21 \%$

Berdasarkan perhitungan koefisien determinasi di atas, didapatkan hasil 50\%, maka Kompensasi mempengaruhi terhadap Kinerja Guru sebesar 50\% dan sisanya sebesar 50\% dipengaruhi oleh faktor-faktor lain.

\section{E. Analisis uji Hipotesis}

Untuk selanjutnya dilakukan uji signifikan korelasi dengan menggunakan uji-t untuk mengetahui apakah kompensasi memiliki pengaruh yang signifikan terhadap kinerja guru, maka uji hipotesis dalam penelitian ini adalah:

$$
\begin{aligned}
& \mathrm{t}= \frac{\mathrm{r} \sqrt{\mathrm{n}-2}}{\sqrt{1-\mathrm{r}^{2}}} \\
& \text { keterangan : } \mathrm{r} \quad=\text { koefisien korelasi } \\
& \mathrm{n} \quad=\text { jumlah responden } \\
& \mathrm{r}^{2}=\text { koefisien determinasi } \\
& \mathrm{t} \quad=\mathrm{t}_{\text {hitung yang selanjutnya dibandingkan dengan } \mathrm{t}_{\text {tabel }}} \\
& \quad \text { diketahui: } \\
& \mathrm{r} \quad=0,708 \\
& \mathrm{n} \quad=60 \\
& \mathrm{r} \quad=(0,708)^{2} \\
& \mathrm{t}=\mathrm{thitung} \text { yang selanjutnya dibandingkan dengan } \mathrm{t} \text { tabel } \\
& \mathrm{t}=\frac{0,708 \sqrt{60-2}}{\sqrt{1-(0,708)^{2}}} \\
& \mathrm{t}=\frac{0,708 \sqrt{58}}{\sqrt{1-0,501}} \\
& \mathrm{t}=\frac{0,708 \cdot 7,615773}{\sqrt{1-0,501}}
\end{aligned}
$$




$$
\begin{aligned}
& \mathrm{t}=\frac{0,708 \cdot 7,615773}{0,499} \\
& \mathrm{t}=\frac{5,391}{0,499} \\
& \mathrm{t}=10,805545 \\
& t=10,805 \\
& \text { sedangkan } t_{\text {tabel }} \text { dicari dengan cara: } \\
& \alpha=\text { taraf kepercayaan } \\
& \mathrm{n} \quad=\text { banyaknya responden } \\
& 2=\text { banyaknya variabel } \\
& \mathrm{t}(\mathrm{dk}=\mathrm{n}-2)
\end{aligned}
$$

\section{Gambar 4.1 Uji Signifikansi Korelasi}

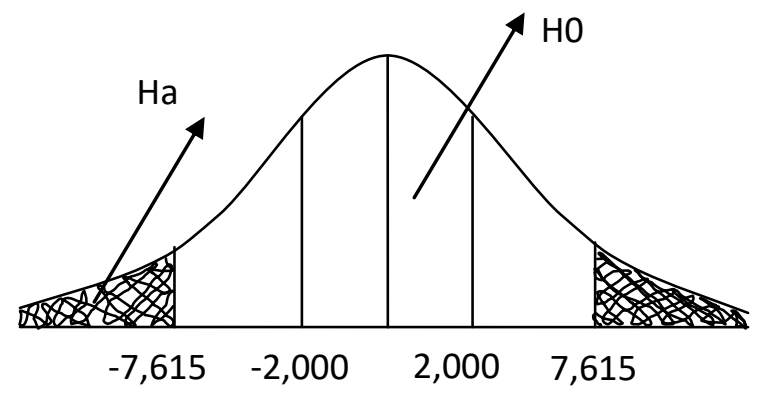

\section{F. Kesimpulan}

1. Pemberian kompensasi yang dilaksanakan Yayasan Pendidikan Waskito, mendapat respon dari karyawan yang sangat baik, penulis menyimpulkan didasarkan pada hasil jawaban seluruh responden yang berjumlah 60 responden dengan 10 pernyataan yang menjawab " sangat setuju " sejumlah 20,14 \% dilanjutkan dengan jawaban " setuju " $37 \%$, selebihnya " ragu-ragu " $13 \%$, " tidak setuju " 20,16 , " sangat tidak setuju“ $1 \%$.

2. Kinerja guru pada Yayasan Pendidikan Waskito, mendapat respon yang sangat baik, penulis menyimpulkan didasarkan pada hasil jawaban seluruh responden yang berjumlah 60 responden dengan 10 pernyataan yang menjawab "sangat setuju " sejumlah $31 \%$ dilanjutkan dengan jawaban " setuju " $94 \%$, selebihnya " ragu-ragu " $13 \%$, " tidak setuju " $4 \%$, " sangat tidak setuju" $2 \%$

3. Pengaruh kompensasi terhadap kinerja guru yaitu sebesar $\mathbf{r}=\mathbf{0 , 7 0 8 2 0 8}$. Hal ini berarti semakin tinggi kompensasi yang diterima seseorang, maka semakin tinggi pula tingkat kinerja pengajarnya. Sebaliknya jika kompensasi yang diterima semakin rendah, maka tingkat kinerjanya pada Yayasan Pendidikan Waskito juga semakin rendah. Dan nilai Koefisien Determinasi $\mathbf{R}=\mathbf{5 0 , 2 1} \%$ ini menunjukan 
bahwa pengaruh kompensasi terhadap kinerja Guru pada Yayasan Pendidikan Waskito sebesar 50,21\%. Sedangkan selebihnya yaitu $\mathbf{1 0 0 \%}-\mathbf{5 0 , 2 1 \%}=\mathbf{4 9 , 7 9} \%$ dipengaruhi oleh faktor lain.

\section{Saran}

1. Pada faktor kompensasi masih perlu ditingkatkan kekompensasian yang dilakukan kepada guru maka dapat mempertahankan kinerja guru pada Yayasan Pendidikan Waskito, sehingga guru akan merasa meningkatkan kedisiplinan dalam berkerja dan dapat lebih termotivasi serta dapat meningkatkan kinerja.

2. Kinerja guru tidak hanya diukur dari kekompensasian yang diterapkan oleh masing-masing individual saja, tetapi peranan pimpinan dalam memberikan motivasi serta perhatian-perhatian yang diberikan Yayasan Pendidikan Waskito serta meningkatkan kompensasi untuk guru sehingga guru merasa dihargai dan nyaman dalam berkerja juga bisa menjadi dorongan yang kuat.

\section{DAFTAR PUSTAKA}

Fauzi A \& basri M, “manajemen sumber daya manusia untuk perusahaan", edisi kedua, cetakan ketiga, penerbit PT raja grafindo, 2010.

Flippo B E, “manajemen personalia”, edisi keenam, jilid II, penerbit erlangga, Jakarta

Handoko H T, “manajemen personalia \& sumber daya manusia”, edisi ke dua, cetakan kesepuluh, penerbit BPFE, Yogyakarta, 1996.

Hariandja E T M, “ manajemen sumber daya manusia”, cetakan ke tiga, penerbit PT Grafindo, Jakarta, 2005.

http://id.wikipedia.org/wiki/Kinerja, di unduh tanggal 27 desember 2011 jam 08.35 WIB

http://id.wikipedia.org/wiki/Kinerja, di unduh tanggal 27 desember 2011 jam 08.35 WIB

Malayu Hasibuan S.P,"Manajemen Sumber Daya Manusia”, Edisi Revisi, Cetakan Ketujuh, Penerbit PT Bumi Aksara, Jakarta, 2005. 